\title{
Front Matter: Volume 11297
}

, "Front Matter: Volume 11297," Proc. SPIE 11297, Complex Light and Optical Forces XIV, 1129701 (5 March 2020); doi: 10.1117/12.2569828

SPIE. Event: SPIE OPTO, 2020, San Francisco, California, United States 


\title{
PROCEEDINGS OF SPIE
}

\section{Complex Light and Optical Forces XIV}

\author{
David L. Andrews \\ Enrique J. Galvez \\ Halina Rubinsztein-Dunlop \\ Editors
}

4-5 February 2020

San Francisco, California, United States

Sponsored and Published by

SPIE 
The papers in this volume were part of the technical conference cited on the cover and title page. Papers were selected and subject to review by the editors and conference program committee. Some conference presentations may not be available for publication. Additional papers and presentation recordings may be available online in the SPIE Digital Library at SPIEDigitalLibrary.org.

The papers reflect the work and thoughts of the authors and are published herein as submitted. The publisher is not responsible for the validity of the information or for any outcomes resulting from reliance thereon.

Please use the following format to cite material from these proceedings:

Author(s), "Title of Paper," in Complex Light and Optical Forces XIV, edited by David L. Andrews, Enrique J. Galvez, Halina Rubinsztein-Dunlop, Proceedings of SPIE Vol. 11297 (SPIE, Bellingham, WA, 2020) Seven-digit Article CID Number.

ISSN: 0277-786X

ISSN: 1996-756X (electronic)

ISBN: 9781510633575

ISBN: 9781510633582 (electronic)

Published by

SPIE

P.O. Box 10, Bellingham, Washington 98227-0010 USA

Telephone +1 3606763290 (Pacific Time) · Fax +1 3606471445

SPIE.org

Copyright (c) 2020, Society of Photo-Optical Instrumentation Engineers.

Copying of material in this book for internal or personal use, or for the internal or personal use of specific clients, beyond the fair use provisions granted by the U.S. Copyright Law is authorized by SPIE subject to payment of copying fees. The Transactional Reporting Service base fee for this volume is $\$ 21.00$ per article (or portion thereof), which should be paid directly to the Copyright Clearance Center (CCC), 222 Rosewood Drive, Danvers, MA 01923. Payment may also be made electronically through CCC Online at copyright.com. Other copying for republication, resale, advertising or promotion, or any form of systematic or multiple reproduction of any material in this book is prohibited except with permission in writing from the publisher. The CCC fee code is $0277-$ $786 \mathrm{X} / 20 / \$ 21.00$.

Printed in the United States of America by Curran Associates, Inc., under license from SPIE.

Publication of record for individual papers is online in the SPIE Digital Library.

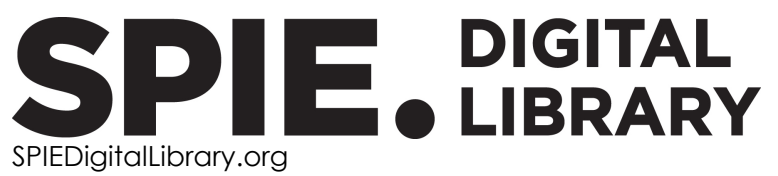

Paper Numbering: Proceedings of SPIE follow an e-First publication model. A unique citation identifier (CID) number is assigned to each article at the time of publication. Utilization of CIDs allows articles to be fully citable as soon as they are published online, and connects the same identifier to all online and print versions of the publication. SPIE uses a seven-digit CID article numbering system structured as follows:

- The first five digits correspond to the SPIE volume number.

- The last two digits indicate publication order within the volume using a Base 36 numbering system employing both numerals and letters. These two-number sets start with $00,01,02,03,04$, 05, 06, 07, 08, 09, OA, OB ... 0Z, followed by 10-1Z, 20-2Z, etc. The CID Number appears on each page of the manuscript. 


\section{Contents}

$\begin{aligned} \vee & \text { Authors } \\ \text { vii } & \text { Conference Committee }\end{aligned}$

FUNDAMENTALS OF COMPLEX LIGHT

1129702 Conceptualization of the photon for quanta of structured light (Invited Paper) [1 1297-1]

1129704 Quantum signatures in the classical limit of electromagnetic waves [11297-3]

1129705 Closed-form analytical Mie theory of vector complex source vortices [11297-4]

1129706 Computation of spot diagrams of different vector beams using geometrical exact ray tracing [11297-5]

NOVEL INTERACTIONS FOR COMPLEX LIGHT GENERATION

1129708 Size-selective optical printing of silicon nanoparticles through their dipolar magnetic resonance [11297-7]

MANIPULATION AND INTERACTIONS WITH LIGHT

11297 OB Patterning ultrafine metal nanoparticles using optoelectronic tweezers (OET) [1 1297-11]

11297 OC Rayleigh and Raman optical activity with Laguerre-Gaussian twisted light [1 1297-12]

OPTICAL FIELDS AND FORCES

11297 OF Non-conservative instabilities in optical vacuum traps (Invited Paper) [11297-14]

11297 Ol Vacuum optomechanics of optically levitated objects: determination of nonlinear properties of the optical trap [11297-17]

11297 0J Continuous symmetries and conservation laws in chiral media [11297-18]

11297 OK Understanding particle trajectories by mapping optical force vortices [11297-19] 
GENERATION AND COMMUNICATION

$1129700 \quad$ GRIN lens: a new element for complex vectorial beam modulation [1 1297-24]

PROPAGATION

11297 OT Higher-order Bessel beams integrated with time (HOBBIT) for dynamic structured light control (Invited Paper) [1 1297-29]

11297 OW Controlling the spectral rotation of ultrashort vortex pulses [11297-32]

11297 OY Transport properties of optical fibres with high numerical apertures [1 1297-34]

\section{POSTER SESSION}

$112970 Z$ Estimation of maximum translation speed of a trapped particle in holographic optical tweezers [11297-35]

1129710 Mode conversion in nanophotonic waveguides via symmetry breaking optomechanical near-field interactions [1 1297-36] 


\title{
Authors
}

Numbers in the index correspond to the last two digits of the seven-digit citation identifier (CID) article numbering system used in Proceedings of SPIE. The first five digits reflect the volume number. Base 36 numbering is employed for the last two digits and indicates the order of articles within the volume. Numbers start with 00, 01, 02, 03, 04, 05, 06, 07, 08, 09, OA, OB...0Z, followed by 10-1Z, 20-2Z, etc.

\author{
Andrews, David L., 02 \\ Arita, Y., OF \\ Barcikowski, Stephan, 08 \\ Barnett, Stephen M., OJ \\ Berškys, Justas, 05 \\ Bock, M., OW \\ Booth, Martin J., 00 \\ Boruah, Bosanta R., 06, $0 Z$ \\ Brzobohaty, Oto, OF, Ol \\ Buddha, S. S. Goutam, $\mathrm{OZ}$ \\ Chiarelli, Germán, 08 \\ Cižmár, T., OY \\ Cortes, Emiliano, 08 \\ Crimin, Frances, 0J \\ Dai, Ben, 00 \\ Dai, Kunjian, OT \\ Dholakia, K., OF \\ Filip, Radim, OI \\ Flajsmanova, Jana, Ol \\ Forbes, Kayn A., OC \\ Gargiulo, Julián, 08 \\ Götte, Jörg, OJ \\ Grunwald, R., OW \\ $\mathrm{He}, \mathrm{Chao}, 0 \mathrm{O}$ \\ Jakl, Petr, OF, Ol \\ Jakobi, Jurij, 08 \\ Johnson, Eric G., OT \\ Kalita, Ranjan, $\mathrm{OZ}$ \\ Kaňka, J., OF \\ König, Matthias, 08 \\ Kozak, Dmitry A., 10 \\ Laurinavičius, Klemensas, 05 \\ Lenton, Isaac C. D., OK \\ Li, Weizhen, OB \\ Li, Wenzhe, OT \\ Liebmann, M., OW \\ Lin, Jianyu, $0 \mathrm{O}$ \\ Mackinnon, Neel, 0J \\ Maier, Stefan A., 08 \\ Malik, Karuna Sindhu, 06, $0 Z$ \\ Miller, J. Keith, OT \\ Morgan, Kaitlyn S., OT \\ Neale, Steven L., OB \\ Nieminen, Timo A., OK \\ O'Donnell, Caitie, OT \\ Olmos-Trigo, Jorge, 08 \\ Orlov, Sergej, 05 \\ Partanen, Mikko, 04 \\ Pruessner, Marcel W., 10
}

Rabinovich, William S., 10

Rubinsztein-Dunlop, Halina, OK

Sáenz, Juan José, 08

Schlücker, Sebastian, 08

Schumacher, Ludmilla, 08

Siler, Martin, OF, OI

Simpson, Stephen H., OF, Ol, OY

Stefani, Fernando D., 08

Stievater, Todd H., 10

Stilgoe, Alex B., OK

Svak, V., OF, 01

Tang, Song, OB

Treffer, A., OW

Tulkki, Jukka, 04

TYc, T., OY

Violi, Ianina L., 08

Wallrabe, U., OW

Walton, Finlay, OB

Watkins, Richard J., OT

White, Graham, OT

$\mathrm{Xi}$, Peng, 00

Zaza, Cecilia, 08

Zemanek, Pavel, OF, Ol 
Proc. of SPIE Vol. 11297 1129701-6 Downloaded From: https://www.spiedigitallibrary.org/conference-proceedings-of-spie on 26 Apr 2023
Terms of Use: https://www.spiedigitallibrary.org/terms-of-use 


\section{Conference Committee}

Symposium Chairs

Sailing He, KTH Royal Institute of Technology (Sweden) and Zhejiang University (China)

Yasuhiro Koike, Keio University (Japan)

Symposium Co-chairs

Connie J. Chang-Hasnaian, University of California, Berkeley (United States)

Graham T. Reed, Optoelectronics Research Centre, University of Southampton (United Kingdom)

Program Track Chair

David L. Andrews, University of East Anglia (United Kingdom)

Conference Chairs

David L. Andrews, University of East Anglia (United Kingdom)

Enrique J. Galvez, Colgate University (United States)

Halina Rubinsztein-Dunlop, The University of Queensland (Australia)

Conference Program Committee

Cornelia Denz, Westfälische Wilhelms-Universität Münster (Germany)

Kishan Dholakia, University of St. Andrews (United Kingdom)

Wolfgang A. Ertmer, Leibniz Universität Hannover (Germany)

Andrew Forbes, University of the Witwatersrand, Johannesburg (South Africa)

Jesper Glückstad, OptoRobotix ApS (Denmark)

Jörg B. Götte, Nanjing University (China)

Rüdiger Grunwald, Max-Born-Institut für Nichtlineare Optik und

Kurzzeitspektroskopie (Germany)

Simon Hanna, University of Bristol (United Kingdom)

Jandir M. Hickmann, Universidade Federal do Rio Grande do Sul (Brazil)

Martin P. J. Lavery, University of Glasgow (United Kingdom)

Ting-Hua Lu, National Taiwan Normal University (Taiwan)

Lorenzo Marrucci, Università degli Studi di Napoli Federico II (Italy)

Giovanni Milione, NEC Laboratories America, Inc. (United States)

Miles J. Padgett, University of Glasgow (United Kingdom) 
Daryl Preece, Beckman Laser Institute and Medical Clinic (United States)

Monika Ritsch-Marte, Medizinische Universität Innsbruck (Austria) Nirmal K. Viswanathan, University of Hyderabad (India)

\section{Session Chairs}

1 Fundamentals of Complex Light

Enrique J. Galvez, Colgate University (United States)

2 Novel Interactions for Complex Light Generation

Kayn A. Forbes, University of East Anglia (United Kingdom)

3 Manipulation and Interactions with Light

Eileen Otte, Westfälische Wilhelms-Universität Münster (Germany)

4 Optical Fields and Forces

Martin P. J. Lavery, University of Glasgow (United Kingdom)

5 Generation and Communication

Andrew Forbes, University of the Witwatersrand, Johannesburg (South Africa)

6 Structured Light

Enrique J. Galvez, Colgate University (United States)

7 Propagation

Halina Rubinsztein-Dunlop, The University of Queensland (Australia) 